\title{
Cesium Treatment Depresses Glycolysis Pathway in HeLa Cell
}

\author{
Daisuke Kobayashi Natsumi Nishimura Akihiro Hazama \\ Department of Cellular and Integrative Physiology, School of Medicine, Fukushima Medical University, \\ Fukushima, Japan
}

\section{Key Words}

Aerobic glycolysis $•$ Cesium $•$ Glycolysis suppression $・$ HeLa cell $•$ Pyruvate kinase

\begin{abstract}
Background/Aims: Cesium (Cs) is an alkali metal element that is of no essential use for humans; it has no known beneficial function that is verified by clinical research. When used as an alternative cancer therapy, it even causes toxicity in high doses. Thus, before using Cs as treatment in clinical settings, it is important to clearly determine its biological effects on cells. However, Cs was found to suppress the proliferation of human cervical cancer cells in a dosedependent manner, and it was assumed that Cs inhibits the glycolysis pathway. In this study, we clearly determined the step of the glycolysis pathway that is affected by Cs. Methods: The glycolytic enzyme expressions, activities, and metabolite concentrations in HeLa cells were measured by PCR, western blotting, and enzymatic methods, after treating the cells with Cs for 3 days. Results: Cs treatment decreased transcriptional and expression levels of hexokinase, glyceraldehyde-3-phosphate dehydrogenase, pyruvate kinase (PK), and lactate dehydrogenase and the activity of PK. Analysis of glycolysis pathway metabolites revealed that Cs treatment reduces lactate level and increases the level of nicotinamide adenine dinucleotide (oxidized form, NAD+); however, it did not affect the levels of pyruvate and nicotinamide adenine dinucleotide (reduced form, NADH). Increase of the $\left[\mathrm{NAD}^{+}\right] /[\mathrm{NADH}]$ ratio and decrease of the [lactate]/[pyruvate] ratio indicate that Cs treatment inhibits the aerobic glycolysis pathway. Conclusion: $\mathrm{Cs}$ treatment inhibits PK activity and increases the [NAD+]/[NADH] ratio. Hence, Cs has been determined to inhibit glycolysis, especially the aerobic glycolysis pathway. These results suggest that suppression of HeLa cell proliferation following Cs treatment was caused by inhibition of aerobic glycolysis by Cs.
\end{abstract}

\section{Introduction}

Like potassium (K) and sodium (Na), cesium (Cs) is an alkali metal element. The bare ion radius of alkali metal elements increases in a molecular weight-dependent manner (e.g., $0.169 \mathrm{~nm}$ for $\mathrm{Cs}^{+}$and $0.133 \mathrm{~nm}$ for $\mathrm{K}^{+}$); however, the hydrated radius of $\mathrm{Cs}^{+}$has been 


\section{Cellular Physiology Cell Physiol Biochem 2021;55:477-488 \\ \begin{tabular}{ll|l} 
and Biochemistry $\begin{array}{l}\text { DOI: 10.33594/000000399 } \\
\text { Published online: } 11 \text { August } 2021\end{array}$ & $\begin{array}{l}\text { C } 2021 \text { The Author(s). Published by } \\
\text { Cell Physiol Biochem Press GmbH\&Co. KG }\end{array}$ \\
\hline
\end{tabular} \\ Kobayashi et al.: Cesium Depresses Glycolysis Pathway}

determined to be the same as that of $\mathrm{K}^{+}(0.33 \mathrm{~nm})$ [1]. Therefore, it was assumed that $\mathrm{Cs}^{+}$was transported via $\mathrm{K}^{+}$transporters. Human intake of Cs is usually via food crops grown on arable land. Cs levels in rice, wheat, and soybeans were reported to be $0.0003-0.065 \mathrm{mg} / \mathrm{kg}$-dry weight [2, 3], approximately $0.1 \mathrm{mg} / \mathrm{kg}$-dry weight [4], and $0.016-0.325 \mathrm{mg} / \mathrm{kg}$-dry weight [5], respectively. It has been hypothesized that ingested Cs is distributed around the whole body. Upon administration to humans, Cs is distributed to the brain, liver, kidney, and blood [6-14]. The half-life of Cs in a human adult male is 50-150 days [15-18].

Cs has no known beneficial function in human that is verified by clinical research; furthermore, it causes toxicity in high doses [6-11]. Cesium chloride ( $\mathrm{CsCl}$ ) and cesium carbonate $\left(\mathrm{Cs}_{2} \mathrm{CO}_{3}\right)$ have been used in clinical settings as alternative cancer therapy $[10,12-$ $14]$, but their safety is yet to be assessed, and the efficacy of Cs in cancer therapy has never been demonstrated in controlled trials; however, relief of cancer-associated pain and rapid shrinkage of tumor masses have been reported [12,13]. The Food and Drug Administration has added warnings to the labeling of $\mathrm{CsCl}$ [19]. The side effects of Cs include QT prolongation, hypokalemia, seizures, cardiac arrhythmia (Torsades de pointes), fainting, and cardiac arrest [20]. However, it has been reported that some patients on Cs supplementation of different doses stay alive for 10-150 days [11,14], and some others for up to 1 year [18]. High-dose Cs oral intake or injection seems to be associated with adverse effects [11]. Therefore, to use Cs as treatment in clinical settings, it is important that we clearly determine the biological effects of Cs on cells.

In general, mammalian cells take up sugar to produce energy via the glycolysis pathway. The expression pattern of several glycolytic enzymes has been determined to be vary between the normal and tumor cells. In mammals, hexokinase (HK) has been shown to exist in the following four isozymes: type I, type II, type III, and type IV [21, 22]. It has been shown that the brain and kidney mainly express type I HK, while the skeletal muscles express type II HK. Type II HK is often expressed in poorly differentiated and rapidly growing tumors, thus playing a pivotal role in facilitating the cell proliferation and survival of highly malignant tumor cells $[23,24]$. In mammals, pyruvate kinase (PK) is expressed in four isoforms, namely, PKL, PKR, PKM1, and PKM2. PKL and PKR are expressed in the liver and red blood cells. PKM1 is expressed in most adult tissues, and PKM2 is a splice variant of the PKM gene and is expressed in tumor tissues and carcinoma cell lines. The PKM2 isoform is important for cancer metabolism and tumor growth $[25,26]$. Lactate dehydrogenase (LDH) is a heterotetrameric enzyme consisting of two subunits, namely, subunit A and subunit B. It is expressed in five different isoforms in mammals. Isoform LDH1 (rich in subunit B) is predominantly expressed in tissues that undergo aerobic metabolism, whereas isoform LDH5 (rich in subunit A) is predominantly expressed in tissues that undergo anaerobic metabolism. In aerobic environments (Air: $\left.\mathrm{CO}_{2}=95: 5\right)$, isoform LDH3 and LDH4 are predominantly expressed even though all LDH isoforms are expressed in human cervical cancer HeLa cells [27]. When cell environments change from aerobic to anaerobic, isoform LDH1 expression and total LDH activity have been observed to decrease. Thus, glycolytic enzymes are highly involved in tumor cell proliferation and survival.

With regard to the effect of Cs on cultured cells, we previously reported that $\mathrm{CsCl}$ suppresses the proliferation of HeLa cells, murine embryonic fibroblast NIH/3T3 cells [28, 29]. When $\mathrm{CsCl}$ added to the extracellular space enters the intracellular space, intracellular $\mathrm{Cs}^{+}$concentration will then increase and $\mathrm{K}^{+}$concentration decrease. $\mathrm{PK}$, which is one of the glycolytic enzymes, catalyzes the transfer of a phosphate group from phosphoenolpyruvate (PEP) to adenosine diphosphate (ADP), which in turn yields pyruvate and adenosine triphosphate (ATP) with $\mathrm{K}^{+}$as a co-factor. $\mathrm{Cs}^{+}$size is considered to comparable that of $\mathrm{K}^{+}$; therefore, increase in intracellular $\mathrm{Cs}^{+}$level inhibits PK activity. We assume that by decreasing $\mathrm{PK}$ activity using $\mathrm{Cs}^{+}$treatment, it will lead to the suppression of cell proliferation; however, whether $\mathrm{Cs}^{+}$inhibits glycolysis pathway is yet to be established.

In this study, we examined the effect of Cs on glycolysis pathway through glycolytic enzyme expression and activity and glycolytic metabolite concentration. We then determined the step of the glycolysis affected by Cs. 


\section{Cellular Physiology Cell Physiol Biochem 2021;55:477-488 \\ \begin{tabular}{ll|l} 
and Biochemistry & $\begin{array}{l}\text { DOI: 10.33594/000000399 } \\
\text { Published online: } 11 \text { August } 2021\end{array}$ & $\begin{array}{l}\text { C } 2021 \text { The Author(s). Published by } \\
\text { Cell Physiol Biochem Press GmbH\&Co. KG }\end{array}$
\end{tabular} \\ Kobayashi et al.: Cesium Depresses Glycolysis Pathway}

\section{Materials and Methods}

\section{Chemicals and enzymes}

General chemical reagents were purchased from FUJIFILM Wako Pure Chemical Corporation (Osaka, Japan) and Sigma-Aldrich Japan K.K. (Tokyo, Japan). To measure the glycolytic enzyme activity, ATP, ADP, nicotinamide adenine dinucleotide reduced form (NADH), nicotinamide adenine dinucleotide phosphate (oxidized form, $\mathrm{NADP}^{+}$), hexokinase (HK), glucose-6-phosphate dehydrogenase (G6PDH), PK, and alcohol dehydrogenase $(\mathrm{ADH})$ were obtained from Oriental Yeast. Co. Ltd. (Tokyo, Japan); lactose dehydrogenase (LDH) was purchased from Sigma; and PEP, D-3-phosphoglycerate (3-PGA), and 3-phosphoglycerate phosphokinase (PGK) were also obtained from Sigma. We then purchased 2-(4-Iodophenyl)-3(4-nitrophenyl)-5-(2,4-disulfophenyl)-2H-tetrazolium, monosodium salt (WST-1), 1-methoxy-5methylphenazinium methyl sulfate (1-Met-PMS), and $N$-ethyl- $N$-(2-hydroxy-3-sulfopropyl)-3-methylaniline sodium salt from Dojindo Laboratories (Kumamoto, Japan). Pyruvate oxidase (PYO) and peroxidase (POD) were obtained from Toyobo Co. Ltd. (Osaka, Japan).

\section{Cell culture}

HeLa cells were routinely cultured in Dulbecco's modified Eagle medium (DMEM \#044-29765; FUJIFILM Wako) supplemented with $10 \%$ fetal bovine serum (FBS) at $37^{\circ} \mathrm{C}$ in a $5 \% \mathrm{CO}_{2}$ humidified incubator. For all experiments, HeLa cells were plated in DMEM, incubated overnight, and incubated in DMEM supplemented with a specific concentration of $\mathrm{CsCl}$. Cs treatment was performed 3 days incubation in all experiments.

\section{Quantitative PCR}

To compare the relative amounts of mRNA for glycolysis-related genes in HeLa cells treated with $10 \mathrm{mM}$ $\mathrm{CsCl}$, we performed semi-quantitative real-time polymerase chain reaction (qPCR). Total RNA was extracted from enzymatically detached HeLa cells using an RNeasy Plus Mini Kit (QIAGEN K. K., Tokyo, Japan), according to the manufacturer's instructions. Reverse transcription (RT) was performed on $2 \mu \mathrm{g}$ of total RNA, calculated from absorbance measured at $260 \mathrm{~nm}$, using a ReverTra Ace qPCR RT Master Mix with gDNA Remover kit (Toyobo), according to the manufacturer's instructions. Primer sequence was obtained from OriGene Technologies, Inc. (Rockville, USA), which was then synthesized at FASMAC Co. Ltd. (Kanagawa, Japan). qPCR using the ABI7300 real-time PCR system was performed according to the manufacturer's instructions. RT samples (2-10 ng of total RNA) were amplified using a THUNDERBIRD SYBR qPCR Mix (Toyobo) to a final volume of $20 \mu \mathrm{L}$. The $28 \mathrm{~S}$ ribosomal RNA (28S-RNA) was used as an internal control. The reaction conditions were as follows: $95^{\circ} \mathrm{C}$ for 1 minute, followed by 40 cycles of $95{ }^{\circ} \mathrm{C}$ for 15 seconds and $60^{\circ} \mathrm{C}$ for 1 minute. Relative amounts of each of mRNA levels were determined by normalization with the 28S-RNA expression level. The following primers were unique for the indicated gene: 28S-RNA ([U13369]) $[30,31]$ forward 5'-GTT CAC CCA CTA ATA GGG AAC GTG A-3', reverse 5'-GAT TCT GAC TTA GAG GGT TCA GT-3'; hHK2 (referred to OriGene Technologies, Inc., Rockville, USA, HP200174) forward 5'-GAG TTT GAC CTG GAT GTG GTT GC-3', reverse 5'-CCT CCA TGT AGC AGG CAT TGC T-3'; hGAPDH [32, 33] forward 5'-TCT CTG CTC CTC CTG TTC GAC-3', reverse 5'-CAA ATG AGC CCC AGC CTT CTC-3'; hLDHA (OriGene, HP208683) forward 5'-GGA TCT CCA ACA TGG CAG CCT T-3', reverse 5'-AGA CGG CTT TCT CCC TCT TGC T-3'; hLDHB (OriGene, HP206024) forward 5'-GGA CAA GTT GGT ATG GCG TGT G-3', reverse 5'-AAG CTC CCA TGC TGC AGA TCC A-3'; hPKM2 (OriGene, HP206306) forward 5'-ATG GCT GAC ACA TTC CTG GAG C-3', reverse 5'-CCT TCA ACG TCT CCA CTG ATC G-3'.

\section{Preparation of crude extract and determination of protein concentration}

Cultured HeLa cells were washed twice using phosphate-buffered saline without $\mathrm{Ca}^{2+}(\mathrm{PBS})$, detached from the cultivation dish using a scraper, and suspended in PBS. The cells were centrifuged at $160 \times g$ for 5 minutes. The collected cells were suspended in PBS with protease inhibitor cocktail (Sigma; P8340); thereafter, the cells were disrupted using an ultrasonic processor (Vibra-Cell ${ }^{\mathrm{TM}} \mathrm{VCX} 130$; Sonics \& Materials, Inc., Newtown, USA). The disruption step was performed at $4{ }^{\circ} \mathrm{C}, 10$-second sonication and 50 -second cooling intervals, and 60-second sonication in total. The disrupted cells suspension was then centrifuged at $15,000 \times g$ for 20 minutes at $4{ }^{\circ} \mathrm{C}$ and the supernatant obtained was used as a crude extract in an enzyme 


\section{Cellular Physiology Cell Physiol Biochem 2021;55:477-488 \\ \begin{tabular}{ll|l} 
and Biochemistry & $\begin{array}{l}\text { DOl: } 10.33594 / 000000399 \\
\text { Published online: } 11 \text { August } 2021\end{array}$ & $\begin{array}{l}\text { C } 2021 \text { The Author(s). Published by } \\
\text { Cell Physiol Biochem Press GmbH\&Co. KG }\end{array}$ \\
\hline
\end{tabular} \\ Kobayashi et al.: Cesium Depresses Glycolysis Pathway}

assay. Protein concentration measurement in the crude extract was performed using Quick Start ${ }^{\mathrm{TM}}$ Bradford Dye Reagent (Bio-Rad Laboratories Inc., CA, USA), according to the manufacturer's instruction. Bovine serum albumin (BSA) was then used as standard protein (Sigma).

\section{Western blotting}

Cultured HeLa cells were washed twice with PBS, detached from the cultivation dish using a scraper, and suspended in cell lysis buffer (9 M urea, $2 \%$ Triton X-100, $1 \%$ dithiothreitol, and $2 \%$ sodium dodecyl sulfate [SDS]). The disruption step was performed at $4{ }^{\circ} \mathrm{C}, 10$-second sonication and 50-second cooling intervals, finally 60 -second sonication in total. The disrupted cells suspension was centrifuged at $15,000 \times g$ for 10 minutes at $4{ }^{\circ} \mathrm{C}$ and the supernatant obtained was utilized as a total protein extract. Equal amounts $(10 \mu \mathrm{g})$ of total protein per lane were separated using $10 \%$ SDS-polyacrylamide gel electrophoresis and were later transferred to a polyvinylidene difluoride membrane. After blocking in PBS containing $3 \%$ BSA, blots were incubated overnight with primary antibodies at a dilution of 1:1000 in the blocking solution. The primary antibodies were obtained from R\&D Systems (Minneapolis, USA), whereas HK (MAB8179), PKM2 (MAB72441), LDHA (MAB9158), LDHB (MAB9205), and GAPDH (ab9485) were obtained from Abcam (Tokyo, Japan). After incubation with primary antibody solution, the membrane was washed in PBS, and incubation with anti-rabbit (\#7074) and anti-mouse (\#7076) horseradish peroxidase-linked secondary antibody (Cell Signaling Technology Japan, K.K., Tokyo, Japan) at a dilution of 1:2000 in blocking solution was performed for 1 hour. After washing the membrane in PBS, detection was performed using Pierce ECL Western Blotting Substrate (Thermo Fisher Scientific K.K., Kanagawa, Japan). Densitometric quantification was performed using Image Lab ${ }^{\mathrm{TM}}$ (Bio-Rad Laboratories, Hercules, California, USA).

\section{Glycolytic enzyme assay}

The activity of each glycolytic enzyme in a crude extract of HeLa cells was measured using spectrophotometric assay. Hexokinase (HK) activity was measured based on NADPH production from glucose coupling with G6PDH at $25^{\circ} \mathrm{C}$. The standard assay cuvette contained $100 \mathrm{mM}$ potassium phosphate (pH 7.4), $10 \mathrm{mM} \mathrm{MgCl}{ }_{2}, 20 \mathrm{mM}$ D-glucose, $1 \mathrm{mM}$ ATP, $0.2 \mathrm{mM} \mathrm{NADP}+$, G6PDH (6 units), and HK from a crude extract of HeLa cells in a final volume of $1 \mathrm{~mL}$. The reaction was initiated by adding D-glucose, and NADPH production was monitored at $340 \mathrm{~nm}$. Meanwhile, glyceraldehyde-3-phosphate dehydrogenase (GAPDH) activity was measured based on a decrease in NADH production from 3-PGA coupling with PGK at $25{ }^{\circ} \mathrm{C}$. The standard assay cuvette contained $100 \mathrm{mM}$ potassium phosphate ( $\mathrm{pH} 7.4$ ), $10 \mathrm{mM} \mathrm{MgCl}, 5 \mathrm{mM}$ ATP, 0.2 mM NADH, 1 mM dithiothreitol, 3 mM 3-PGA, PGK (5 units), and GAPDH from a crude extract of HeLa cells in a final volume of $1 \mathrm{~mL}$. The reaction was initiated by adding 3-PGA, and decrease in NADH was monitored at $340 \mathrm{~nm}$. LDH activity was measured based on decrease in NADH at $25{ }^{\circ} \mathrm{C}$. The standard assay cuvette has been determined to contain $100 \mathrm{mM}$ potassium phosphate ( $\mathrm{pH} 7.4$ ), $20 \mathrm{mM}$ pyruvate, $0.2 \mathrm{mM} \mathrm{NADH}$, and LDH from a crude extract of HeLa cells in a final volume of $1 \mathrm{~mL}$. The reaction was initiated by adding pyruvate, and NADH decrease was monitored at $340 \mathrm{~nm}$. PK activity was measured based on decrease in NADH coupling with $\mathrm{LDH}$ at $25^{\circ} \mathrm{C}$ [28]. The standard assay cuvette contained $100 \mathrm{mM}$ potassium phosphate (pH 7.4), $10 \mathrm{mM} \mathrm{MgCl}_{2}, 2 \mathrm{mM}$ ADP, $2 \mathrm{mM}$ PEP, $0.2 \mathrm{mM} \mathrm{NADH,} \mathrm{LDH} \mathrm{(5} \mathrm{units),} \mathrm{and} \mathrm{PK} \mathrm{from} \mathrm{a} \mathrm{crude} \mathrm{extract}$ of HeLa cells in a final volume of $1 \mathrm{~mL}$. The reaction was initiated by adding ADP, and NADH decrease was monitored at $340 \mathrm{~nm}$. For all enzymes, 1 unit of activity was represented as an absorbance change of $6.22 \mathrm{mM}^{-1} \mathrm{~cm}^{-1}$ per minute at $340 \mathrm{~nm}$.

\section{Determination of intracellular metabolites}

Pyruvate determination was performed by POD/PYO coupling assay using 96-well plates. The standard assay well contained $80 \mathrm{mM}$ potassium phosphate buffer ( $\mathrm{pH}$ 5.8), $0.5 \mathrm{mM} \mathrm{4-aminoantipyrine,} 0.01 \mathrm{mM}$ flavin adenine dinucleotide, $0.2 \mathrm{mM}$ thiamine pyrophosphate, $0.6 \mathrm{mM} \mathrm{N}$-ethyl- $\mathrm{N}$-(2-hydroxy-3-sulfopropyl)3-methylaniline, $2 \mathrm{mM}$ ethylenediamine tetraacetic acid disodium salt, $10 \mathrm{mM} \mathrm{MgSO} 4^{4}$ - 5-unit POD, 2.4-unit PYO, and pyruvate from a crude extract of HeLa cells in a final volume of $0.3 \mathrm{~mL}$. The reaction mixture was then incubated at $25{ }^{\circ} \mathrm{C}$ for $30-60$ minutes and pyruvate-dependent coloring was monitored at $550 \mathrm{~nm}$. Lactate determination was performed using LDH coupling method with 96-well plate. The standard assay well contained $10 \mathrm{mM} \mathrm{N}$-2-hydroxyethylpiperazine-N-2 ethane sulfonic acid (HEPES) buffer (pH 8.0), 0.4 $\mathrm{mM} \mathrm{NAD}{ }^{+}, 22$-unit LDH, chromogenic substrate (WST-1/1-Met-PMS), and lactate from a crude extract of HeLa cells in a final volume of $0.15 \mathrm{~mL}$. The reaction mixture was incubated at $25^{\circ} \mathrm{C}$ for $30-60$ minutes, and 


\section{Cellular Physiology Cell Physiol Biochem 2021;55:477-488 \\ \begin{tabular}{ll|l} 
DOl: 10.33594/000000399 & $\begin{array}{l}\text { O } 2021 \text { The Author(s). Published by } \\
\text { Cell Physiol Biochem Press GmbH\&Co. KG }\end{array}$
\end{tabular} \\ Kobayashi et al.: Cesium Depresses Glycolysis Pathway}

lactate-dependent coloring was monitored at $450 \mathrm{~nm} . \mathrm{NAD}^{+}$and NADH determination was performed using ADH coupling method with 96-well plates. To determine $\mathrm{NAD}^{+}$and NADH, cultured cells were suspended into PBS, equal amounts of extraction solution $(100 \mathrm{mM}$ Na carbonate, $20 \mathrm{mM}$ Na bicarbonate, $0.05 \%$ Triton $\mathrm{X}-100$ ) were added, and the obtained crude extract was centrifugated at 5,000 $\times g$ using Centricut $\mathrm{W}-10$ (Kurabo Industries Ltd., Osaka, Japan). The flow-through fraction was used as the total NAD $/$ NADH fraction. An adequate amount of the fraction was heated at $60^{\circ} \mathrm{C}$ for 30 minutes in order to decompose $\mathrm{NAD}^{+}$, and the NADH fraction was then obtained. The standard assay well contained each fraction (total NAD $/ \mathrm{NADH}$ and NADH fractions) and equal amounts of the assay solution (0.2 M Tris [pH 8.0], $2 \mathrm{M}$ ethanol, 3-unit ADH, and chromogenic substrate) in a final volume of $0.1 \mathrm{~mL}$. The reaction mixture was incubated at $25^{\circ} \mathrm{C}$ for $30-60$ minutes, and NADH-dependent coloring was monitored at $450 \mathrm{~nm}$. The amount of $\mathrm{NAD}^{+}$was calculated from the amounts of total $\mathrm{NAD}^{+} / \mathrm{NADH}$ fraction and $\mathrm{NADH}$ fraction using the following equation: $\mathrm{NAD}^{+}=$total $\mathrm{NAD}^{+} / \mathrm{NADH}-\mathrm{NADH}$.

\section{Results}

Transcriptional levels of glycolysis-related genes

In our previous study [28], Cs has been found to suppress HeLa cell proliferation in a dose-dependent manner and Cs inhibited PK activity in crude extracts. Based on these findings, we hypothesized that Cs treatment may affect glycolysis pathway in HeLa cells. To test this assumption, we performed an analysis of the transcriptional levels of glycolysis-related genes, such as HK2, GAPDH, PKM2, LDHA, and $L D H B$. The transcriptional levels of these genes were then compared between Cs-treated cells and control cells, wherein transcriptional levels were found to be significantly lower in Cs-treated cells than that in the control cells (Fig. 1). The relative transcriptional levels of $H K 2$, GAPDH, PKM2, LDHA, and $L D H B$ in the Cstreated cells were $70.6 \pm 9.0 \%, 22.7 \pm 1.3 \%$, $45.0 \pm 5.7 \%, 38.3 \pm 0.2 \%$, and $32.4 \pm 2.3 \%$, respectively $(\mathrm{n}=4)$. $\mathrm{LDH}$ as a heterotetramer is composed of four subunits. It was previously reported that LDH3 (A2B2) and LDH4 (A3B1) are the major LDH isoforms in HeLa cells and that culturing condition can affect the LDH composition [27]. As has been shown in Fig. 1, the transcriptional level of $L D H A$ was higher than that of $L D H B$, and this is consistent with the results of the previous study [27]. However, the transcription levels of $\angle D H A$ and $\angle D H B$ in the Cs-treated cells were found to decrease; hence, Cs treatment did not affect LDH composition but decreased LDH transcription.

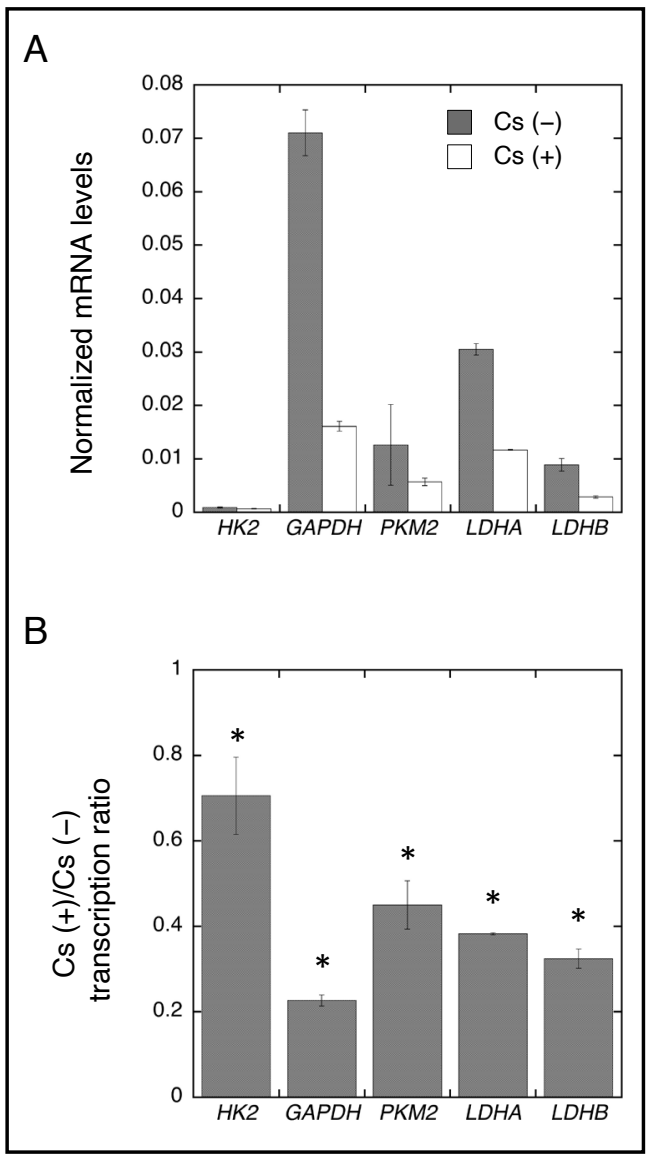

Fig. 1. Transcriptional levels of glycolysis-related genes decrease following Cs treatment. A, mRNA levels of each glycolysis-related gene is determined by normalization with 28S rRNA. Data shows the means of four measurements, and the error bars indicate standard deviations in the absence (black bar) and in the presence (white bar) of $10 \mathrm{mM} \mathrm{CsCl}$. B, Relative mRNA levels of glycolysis-related genes compared to mRNA levels of control cells. The data shows the means of the four measurements, and the error bars indicate standard deviations. Significant differences between values obtained in the absence and in the presence of $10 \mathrm{mM} \mathrm{CsCl}$ are indicated by asterisks ( $\mathrm{p}<0.05$ using Student's t-test). 


\section{Cellular Physiology Cell Physiol Biochem 2021;55:477-488 \\ \begin{tabular}{ll|l} 
and & DOl: 10.33594/000000399 & O 2021 The Author(s). Published by \\
Cell Physiol Biochem Press GmbH\&Co. KG
\end{tabular} \\ Kobayashi et al.: Cesium Depresses Glycolysis Pathway}

\section{Expression levels and activities of glycolytic enzymes}

The expression levels of glycolysis-related proteins including HK, GAPDH, PKM2, LDHA, and LDHB were evaluated using Western blot analysis (Fig. 2). The relative expression levels of HK, GADH, PKM2, LDHA, and LDHB in Cs-treated cells were $0.82 \pm 0.11,0.83 \pm 0.10,0.68 \pm$ $0.19,0.80 \pm 0.08$, and $0.88 \pm 0.04$, respectively $(n=3)$. Compared to the control cells, all the protein expression levels in the Cs-treated cells have been observed to decrease significantly ( $t$-test, $\mathrm{p}<0.05$ ). Although the transcriptional level of LDHA was higher than that of LDHB as shown in Fig. 1, the detected signal intensities of LDHB appeared to be stronger than that of LDHA as shown in Fig. 2A. This disparity may be attributed to the antibody reactivity against each target protein. Enzyme activities in crude extracts of cells with and without Cs treatment were then measured (Fig. 3). HK activity in the Cs-treated cells and control cells was 0.03 $\pm 0.01 \mu \mathrm{mol} \mathrm{NADPH} / \mathrm{min} / \mathrm{mg}$-protein and $0.03 \pm 0.003 \mu \mathrm{mol} \mathrm{NADPH} / \mathrm{min} / \mathrm{mg}$-protein, respectively $(\mathrm{n}=4)$. Similarly, GAPDH activity in the Cs-treated cells and the control cells was $0.88 \pm 0.30 \mu \mathrm{mol} \mathrm{NADH} / \mathrm{min} / \mathrm{mg}$-protein and $0.32 \pm 0.05 \mu \mathrm{mol} \mathrm{NADH} / \mathrm{min} / \mathrm{mg}$-protein, respectively $(n=4)$; PK activity in the Cs-treated cells and control cells was $0.12 \pm 0.01 \mu \mathrm{mol}$ $\mathrm{NADH} / \mathrm{min} / \mathrm{mg}$-protein and $0.10 \pm 0.02 \mu \mathrm{mol} \mathrm{NADH} / \mathrm{min} /$ mg-protein, respectively $(\mathrm{n}=4)$; and LDH activity in the Cs-treated cells and control cells was $0.15 \pm 0.02 \mu \mathrm{mol} \mathrm{NADH} / \mathrm{min} /$ mg-protein and $0.16 \pm 0.02 \mu \mathrm{mol} \mathrm{NADH} / \mathrm{min} / \mathrm{mg}$-protein, respectively $(\mathrm{n}=4)$. The relative activities of HK, GAPDH, PK, and LDH in the Cs-treated cells were 1.02 times, 0.36 times, 0.83 times, and 1.03 times the corresponding values in the control cells, respectively. GAPDH and PK activities in the Cs-treated cells decreased significantly compared to that in the control cells ( $t$-test, $p<0.05$ ), and the activities of the other enzymes in the Cs-treated cells were not significantly different from those in the control cells.

\section{Glycolytic metabolites}

In the aerobic glycolysis pathway in tumor cells, PK produces pyruvate and ATP from PEP and ADP; subsequently, the pyruvate and NADH generated by GAPDH reaction are utilized in order to produce lactate and $\mathrm{NAD}^{+}$by $\mathrm{LDH}$ reaction. Moreover, in tumor cells, the concentrations of pyruvate, lactate, $\mathrm{NADH}$, and $\mathrm{NAD}^{+}$and the ratio of lactate to pyruvate ([lactate]/[pyruvate]) and the ratio of $\mathrm{NAD}^{+}$to $\mathrm{NADH}\left(\left[\mathrm{NAD}^{+}\right] /[\mathrm{NADH}]\right)$ have been identified to play a role in cell proliferation. PK activity was found to decrease in Cs-treated cells (Fig. 3); therefore, we assumed that pyruvate concentration decreased in the Cs-treated cells. To confirm the concentration of intracellular metabolites in Cs-treated and control

Fig. 2. Expression levels of glycolytic proteins following Cs treatment. A, Western blot analysis of HK, GAPDH, PKM2, LDHA, and LDHB protein levels in the absence and in the presence of $10 \mathrm{mM} \mathrm{CsCl}$. Equal amounts of protein $(10 \mu \mathrm{g} /$ lane) was loaded. B, Relative expression levels of glycolytic enzymes were analyzed using imaging software. The data shows the means of the three measurements, and the error bar indicate the standard deviations. Significant differences between values obtained in the absence (black bar) and in the presence (white bar) of $10 \mathrm{mM}$ $\mathrm{CsCl}$ are indicated by asterisks ( $p<0.05$ using Student's t-test).

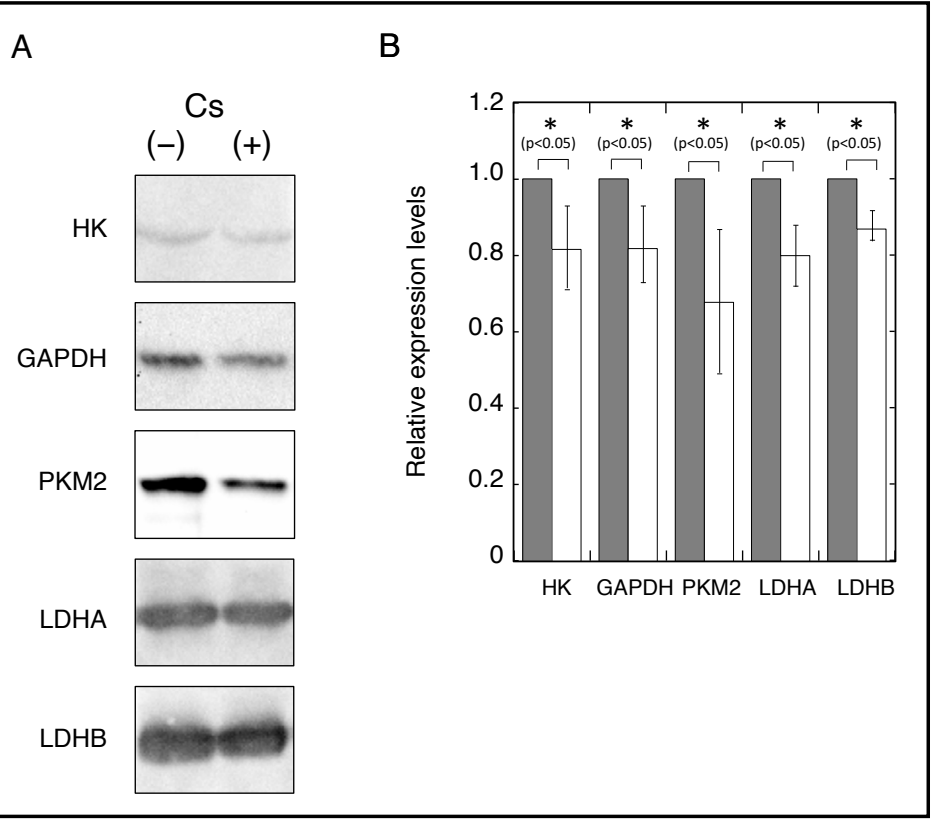




\section{Cellular Physiology Cell Physiol Biochem 2021;55:477-488 \begin{tabular}{ll|l} 
and & DOl: 10.33594/000000399 & $\begin{array}{l}\text { O } 2021 \text { The Author(s). Published by } \\
\text { Cell Physiol Biochem Press GmbH\&Co. KG }\end{array}$
\end{tabular}

Fig. 3. Glycolytic enzyme activities decreased following Cs treatment. Glycolysis-related enzyme activity of crude extracts from HeLa cells in the absence (black bar) and in the presence (white bar) of $10 \mathrm{mM} \mathrm{CsCl}$ was measured using spectrophotometric assay. The data shows the means of the four measurements, and the error bars indicate standard deviations. Significant differences between values obtained in the absence and in the presence of $10 \mathrm{mM}$ $\mathrm{CsCl}$ are indicated by asterisks $(\mathrm{p}<0.05$ using Student's t-test).

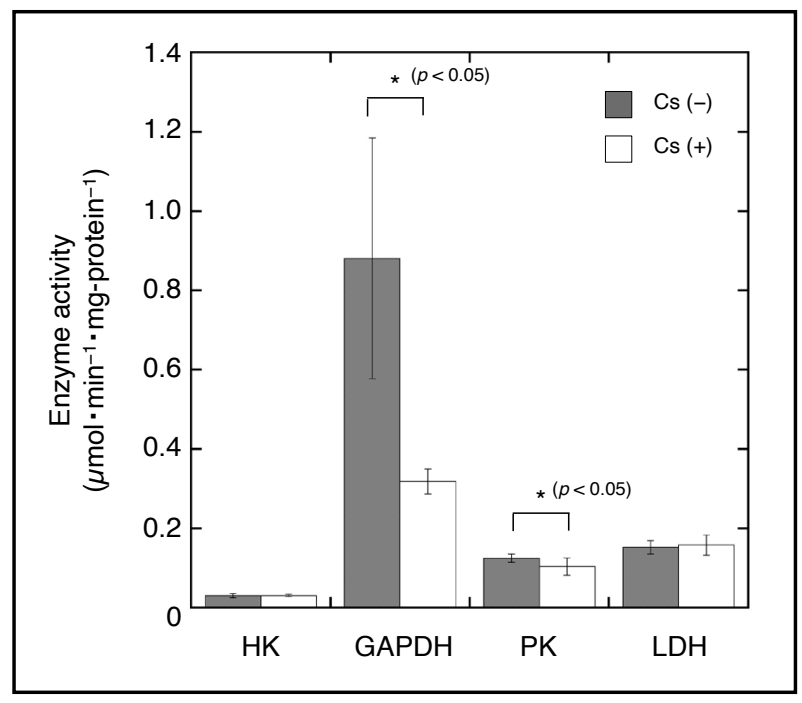

Table 1. Determination of intracellular metabolite concentrations in HeLa cells in the absence and in the presence of $\mathrm{CsCl}$. The data shown are the means of independent measurements and standard deviations. Significant differences between control and Cs-treated cells are indicated by asterisks ( $\mathrm{p}<0.05$ using Student's t-test)

\begin{tabular}{lccccccc}
\hline Metabolite & \multicolumn{3}{c}{ Control } & \multicolumn{2}{c}{$10 \mathrm{mM}$ CsCl } & Significant difference \\
& Mean & \pm & SD & Mean & \pm & SD & $(\mathrm{p}<0.05)$ \\
\hline $\begin{array}{l}\text { Pyruvate } \\
(\mu \text { mol/mg-protein) }\end{array}$ & 15.1 & \pm & 1.8 & 15.3 & \pm & 0.8 & $(\mathrm{n}=3)$ \\
$\begin{array}{l}\text { Lactate } \\
(\mu \mathrm{mol} / \text { mg-protein })\end{array}$ & 172 & \pm & 15 & 103 & \pm & 12 & $(\mathrm{n}=3)^{*}$ \\
$\begin{array}{l}\mathrm{NAD}^{+} \\
(\mu \mathrm{M})\end{array}$ & 1.25 & \pm & 0.18 & 2.21 & \pm & 0.70 & $(\mathrm{n}=5)^{*}$ \\
$\begin{array}{l}\mathrm{NADH} \\
(\mu \mathrm{M})\end{array}$ & 0.08 & \pm & 0.02 & 0.09 & \pm & 0.03 & $(\mathrm{n}=5)$ \\
$\mathrm{NAD}^{+} / \mathrm{NADH}$ ratio & 15.6 & \pm & 2.4 & 24.1 & \pm & 5.9 & $(\mathrm{n}=5)^{*}$ \\
\hline
\end{tabular}

treated cells increased significantly (1.8 times that in control cells). Further, the [lactate]/[pyruvate] ratio of the Cs-treated cells and control cells was 6.7 and 11.4, respectively; then, the [NAD ${ }^{+} /$ [NADH] ratio of each was 24.1 and 15.6, respectively (Table 1). The [NAD $\left.{ }^{+}\right] /[\mathrm{NADH}]$ ratio of Cs-treated cells was found to be 1.5 times higher than that of control cells.

\section{Supplement test for cell growth}

Pyruvate has been identified as an intermediate metabolite of the glycolysis pathway; thus, its addition to culture medium provides energy and a carbon source for anabolic processes, which may recover HeLa cell growth that was suppressed by Cs treatment. Therefore, we assessed cell growth by cell counting following the addition of Cs and pyruvate. Pyruvate had a slightly positive effect on cell growth, and there were no statistically significant differences in cell growth between Cs-treated cells and control cells (Fig. 4). It was found that supplementary pyruvate did not recover HeLa cell growth that was suppressed by Cs treatment. 


\section{Cellular Physiology Cell Physiol Biochem 2021;55:477-488 \\ \begin{tabular}{ll|l} 
and & DOl: 10.33594/000000399 & $\begin{array}{l}\text { O } 2021 \text { The Author(s). Published by } \\
\text { Cell Physiol Biochem Press GmbH\&Co. KG }\end{array}$
\end{tabular} \\ Kobayashi et al.: Cesium Depresses Glycolysis Pathway}

Fig. 4. Pyruvate supplementation did not improve cell growth suppressed by Cs. HeLa cells were cultivated in DMEM supplemented with $10 \% \mathrm{FBS}$ at $37{ }^{\circ} \mathrm{C}$ in a $5 \% \mathrm{CO}_{2}$ humidified incubator in the absence and in the presence of $10 \mathrm{mM} \mathrm{CsCl}$ for 3 days. The medium was supplemented with $1 \mathrm{mM}$ pyruvate. Cell count was performed using trypan blue dye exclusion assay. The data shows the means of the three measurements, and the error bars indicate standard deviations. Significant differences between control cells and each treatment cells are indicated by asterisks ( $\mathrm{p}<0.05$ using Student's t-test).

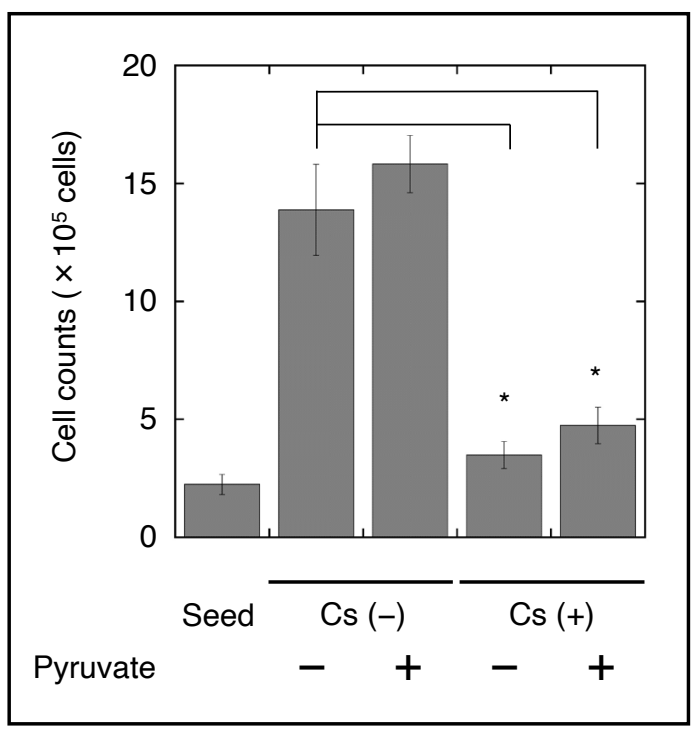

\section{Discussion}

In our previous study, we reported how Cs treatment suppresses HeLa cell growth [28]. The proposed mechanism of cell growth suppression was the inhibition of PK reaction by Cs; therefore, it was assumed that Cs affects the glycolysis pathway. In this study, we aimed to examine the effect of Cs treatment on glycolytic enzymes and metabolites in detail.

Pyruvate, the final product of glycolysis, and its derivative lactate are determined as key metabolites in tumor cells. In normal cells, pyruvate produced from glycolysis enters the mitochondria. Then pyruvate is utilized in the energy production via the tricarboxylic acid cycle and electron transport chain. In contrast, in tumor cells, LDH converts pyruvate and $\mathrm{NADH}$ into lactate and $\mathrm{NAD}^{+}$, which are subsequently utilized in energy production, which is independent of the mitochondria. This is known as the Warburg effect. We postulate that inhibition of PK activity by Cs decreases pyruvate production, and, subsequently, lactate production decreases due to decreasing pyruvate concentration. Comparison of intracellular pyruvate and lactate concentrations between Cs-treated cells and control cells has revealed that pyruvate concentration was comparable between Cs-treated cells and control cells (Table 1). This is supported by a previous study showing that the concentration of PEP, a substrate of PK, in the pancreatic carcinoma cell line PANC-1 dose not increase or decrease even when the cells glycolysis pathway is suppressed [34]. Although energy production via aerobic glycolysis is promoted in tumor cells, mitochondria-dependent energy production is also considered to occur in tumor cells. Pyruvate is an essential metabolite for cell survival; therefore, pyruvate concentration is considered unchanged between Cs-treated and control cells. In contrast, lactate concentration in Cs-treated cells was less than that in the control cells. Conversion of pyruvate to lactate is coupled with the conversion of NADH into $\mathrm{NAD}^{+}$and is mediated by LDH. This step is especially important in aerobic glycolysis as a regeneration step of the $\mathrm{NAD}^{+}$consumed during glycolysis; therefore, decrease of lactate production in tumor cells is considered indicative of tumor cell growth suppression. Further, in cases of glycolysis pathway inhibition using 2-deoxy-D-glucose, which inhibits $\mathrm{HK}$, in cell cultures, intracellular lactate concentration was found to decrease and [NAD $\left.{ }^{+}\right] /$ [NADH] ratio increased [35]. Similarly, when PANC-1 cells were cultured in a poor carbonsource condition, the glycolysis pathway was suppressed, and the concentration of glycolytic metabolites including lactate decreased [34]. To drive glycolysis pathway effectively, it is important to maintain a balance between $\mathrm{NAD}^{+}$and $\mathrm{NADH}$. In a study by Christensen, it was reported that cells with high glycolytic rates had lower $\left[\mathrm{NAD}^{+}\right] /[\mathrm{NADH}]$ ratios and higher [lactate]/[pyruvate] ratios [36]. Although no significant differences in LDH activity were 


\section{Cellular Physiology Cell Physiol Biochem 2021;55:477-488 \\ \begin{tabular}{ll|l} 
and Biochemistry $\begin{array}{l}\text { DOI: 10.33594/000000399 } \\
\text { Published online: } 11 \text { August } 2021\end{array}$ & $\begin{array}{l}\text { C } 2021 \text { The Author(s). Published by } \\
\text { Cell Physiol Biochem Press GmbH\&Co. KG }\end{array}$ \\
\hline
\end{tabular} \\ Kobayashi et al.: Cesium Depresses Glycolysis Pathway}

observed between the Cs-treated cells and the control cells (Fig. 3), the lactate levels of Cstreated cells were found to decrease whereas the $\mathrm{NAD}^{+}$levels of Cs-treated cells increased. Therefore, based on the study of Christensen, it was considered that the glycolysis efficiency of Cs-treated decreased. The proliferation rate of Cs-treated HeLa cells was found to be 0.45 times lower than that of control cells [28]. We hypothesized that suppression of cell proliferation was caused by glycolysis pathway inhibition. Our study findings demonstrating the decrease in [lactate]/[pyruvate] ratio and intracellular lactate concentration. Moreover, significantly different GAPDH activity was observed between Cs-treated cells and control cells. GAPDH activity appeared to be lower in Cs-treated cells than in control cells (Fig. 3). The NAD ${ }^{+}$is necessary for GAPDH activity; thus, it is assumed that $\mathrm{NAD}^{+}$levels increase when glycolysis pathway-mediated GAPDH activity is low.

Transcriptional and expression levels of HK, PK, LDH, and GAPDH were also determined to be lower in Cs-treated cells than in control cells (Fig. 1 and 2). We interpreted this finding as the inhibitory effect of Cs treatment on the glycolysis pathway rather than the effect of Cs as a negative transcriptional regulatory element. LDHA transcriptional levels were found to be higher than LDHB transcriptional levels in Cs-treated and control cells. Cs treatment did not affect the LDH subunits, but it decreased LDH transcriptional levels (Fig. 1). The result on LDH is consistent with the reports of a previous study [27]. Further, in previous studies that reported reduction of LDHA expression, it was shown that LDHA is involved in the initiation, maintenance, and progression of tumor $[37,38]$. The results of this study suggest that reduction of LDH transcriptional levels is one of the leading mechanisms of cell proliferation suppression by Cs treatment. We also assessed glycolytic enzyme activities because transcriptional and expression levels may not directly indicate glycolytic ability. In comparing glycolytic enzyme activities between Cs-treated cells and control cells, it was found that PK activity decreased significantly in Cs-treated cells, but the activity of the other enzymes did not decrease. Although PK reaction needs a $\mathrm{K}^{+}$as a co-factor, it is inhibited by $\mathrm{Cs}^{+}$[28]. In this study, PK activity was measured in a reaction mixture without $\mathrm{Cs}^{+}$(Fig. 3), and the crude extracts from the Cs-treated cells and control cells were determined to be different. The results indicated that intracellular PK activity decreased in the Cs-treated cells. Considering that the PK activity and expression levels in the Cs-treated cells reduced 0.83 -fold and 0.68-fold, respectively, compared to those in the control cells, the reduction of intracellular PK activity may have resulted from the downregulation of intracellular PK expression levels. Further studies are necessary to confirm whether the decrease in PK activity resulted in protein modification by $\mathrm{Cs}^{+}$.

To evaluate cell proliferation, which is suppressed by Cs and can be recovered by addition of extracellular pyruvate, HeLa cells were cultured using pyruvate and Cs. The results showed that the added pyruvate was not affected by the recovery of Cs-dependent cell proliferation suppression (Fig. 4). PK is a key target of Cs action as its transcription, expression, and activity levels are decreased by Cs. In contract, intracellular pyruvate concentration was not affected by Cs treatment. A possible explanation of the conflicting results is that the Cs-treated cells needed the pyruvate, which was consumed in fundamental biological processes such as energy metabolism; however, that did not provide excessive rapid proliferative energy sources. In other words, the results suggest that Cs treatment is deemed more effective in suppressing cell proliferation in hyperproliferative cells than in normal cells.

Although the normal human body contains low amounts of Cs $(0.004 \mathrm{mg} / \mathrm{kg}$ in the brain, $10 \mu \mathrm{g} / \mathrm{L}$ in the serum, and $20 \mu \mathrm{g} / \mathrm{L}$ in the urine) that are obtained from food crops $[6,11]$, Cs concentration in the human body increases dramatically when Cs is taken orally or by intravenous injection. Several studies have reported cases of $\mathrm{CsCl}$ toxicities, and the Cs concentrations were as follows: $1400 \mathrm{mg} / \mathrm{kg}$ (approximately $10.5 \mathrm{mM}$ ) in the liver, $1200-1400 \mathrm{mg} / \mathrm{kg}(9-10.5 \mathrm{mM})$ in the kidney, $780 \mathrm{mg} / \mathrm{kg}(5.9 \mathrm{mM})$ in the brain, $100-990$ $\mathrm{mg} / \mathrm{L}(0.75-7.4 \mathrm{mM})$ in the blood, and $270 \mathrm{mg} / \mathrm{L}(2 \mathrm{mM})$ in the urine of deceased patients $[6,11]$ and $100-250 \mathrm{mg} / \mathrm{L}(0.75-1.9 \mathrm{mM})$ in the blood, $27-50 \mathrm{mg} / \mathrm{L}(0.2-0.38 \mathrm{mM})$ in the serum, and $750 \mathrm{mg} / \mathrm{L}(5.7 \mathrm{mM})$ in the urine of patients who have recovered $[9,18]$. In this 


\section{Cellular Physiology Cell Physiol Biochem 2021;55:477-488 and Biochemistry Dol: 10.33594/000000399 2021 (O) 2021 The Author(s). Published by \\ Kobayashi et al.: Cesium Depresses Glycolysis Pathway}

study, it was considered that $\mathrm{CsCl}$ concentration in vivo can reach $10 \mathrm{mM}$. Moreover, $50 \%$ effective concentration of Cs in HeLa cells and NIH/3T3 cells was $10.9 \mathrm{mM}$ [28] and $2.2 \mathrm{mM}$ [29], respectively. However, the effective concentration of Cs in the human body may vary depending on the cell, tissue, or organ. Since the pharmacological effect of Cs on the human body is not yet well established, we cannot state that oral intake or intravenous injection of Cs is safe for the attenuation of cell proliferation in tumor tissues. However, local Cs treatment may be effective for hyperproliferative epidermal disorders such as hypertrophic scar and keloid.

\section{Conclusion}

Cs treatment has been determined to decrease glycolytic enzyme expression, and intracellular PK activity in HeLa cells. The resultant decrease in lactate concentration and increase in $\left[\mathrm{NAD}^{+}\right] /[\mathrm{NADH}]$ ratio suggest that $\mathrm{Cs}$ treatment depresses aerobic glycolysis and suppresses HeLa cell proliferation.

\section{Acknowledgements}

The authors would like to thank Enago (www.enago.jp) for the English language review.

\section{Author Contributions}

DK and $\mathrm{AH}$ conceived and designed the study, interpreted the results of the experiments, edited and revised the manuscript, and approved the final version of the manuscript. DK and NN performed the experiments and analyzed the data. DK prepared the figures and drafted the manuscript.

\section{Funding}

This work was supported by JSPS KAKENHI Grant Number 26460299.

Statement of Ethics

The authors have no ethical conflicts to disclose.

\section{Disclosure Statement}

The authors have no conflicts of interest to declare.

\section{References}

1 Israelachvili JN: Interactions involving polar molecules, in Israelachvili JN (ed): Intermolecular and surface forces. Revised $3^{\text {rd }}$ edition. Academic Press, Elsevier Inc, 2011, pp 71-90.

2 Tsukada H, Hasegawa H, Hisamatsu S, Yamasaki S: Transfer of 137Cs and stable Cs from paddy soil to polished rice in Aomori, Japan. J Environ Radioactiv 2002;59:351-363.

3 Ohmori Y, Inui Y, Kajikawa M, Nakata A, Sotta N, Kasai K, Uraguchi S, Tanaka N, Nishida S, Hasegawa T, Sakamoto T, Kawara Y, Aizawa K, Fujita H, Li K, Sawaki N, Oda K, Futagoishi R, Tsusaka T, Takahashi S, et al.: Difference in cesium accumulation among rice cultivars grown in the paddy field in Fukushima Prefecture in 2011 and 2012. J Plant Res 2014;127:57-66.

4 Kubo K, Kobayashi H, Nitta M, Takenaka S, Nasuda S, Fujimura S, Takagi K, Nagata O, Ota T, Shinano T: Variations in radioactive cesium accumulation in wheat germplasm from fields affected by the 2011 Fukushima nuclear power plant accident. Sci Rep 2020;10:3744. 


\section{Cellular Physiology Cell Physiol Biochem 2021;55:477-488 \begin{tabular}{ll|l} 
and Biochemistry & $\begin{array}{l}\text { DOl: } 10.33594 / 000000399 \\
\text { Published online: } 11 \text { August } 2021\end{array}$ & $\begin{array}{l}\text { C } 2021 \text { The Author(s). Published by } \\
\text { Cell Physiol Biochem Press GmbH\&Co. KG }\end{array}$ \\
\hline
\end{tabular} \\ Kobayashi et al.: Cesium Depresses Glycolysis Pathway}

5 Takagi K, Kaga A, Ishimoto M, Hajika M, Matsunaga T: Diversity of seed cesium accumulation in soybean mini-core collections. Breed Sci 2015;65:372-380.

6 Khangure SR, Williams ES, Welman CJ: CT brain findings in a patient with elevated brain cesium levels. Neuroradiol J 2013;26:607-609.

7 Neulieb R: Effect of oral intake of cesium chloride: a single case report. Pharmacol Biochem Behav 1984;21:15-16.

8 Saliba W, Erdogan 0, Niebauer M: Polymorphic ventricular tachycardia in a woman taking cesium chloride. Pacing Clin Electrophysiol 2001;24:515-517.

9 Vyas H, Johnson K, Houlihan R, Bauer BA, Ackerman MJ: Acquired long QT syndrome secondary to cesium chloride supplement. J Althrn Complement Med 2006;12:1011-1014.

10 Melnikov P, Zanoni LZ: Clinical effects of cesium intake. Biol Trace Elem Res 2010;135:1-9.

11 Sessions D, Heard K, Kosnett M: Fatal cesium chloride toxicity after alternative cancer treatment. J Altern Complement Med 2013;19:973-975.

12 Brewer AK: The high $\mathrm{pH}$ therapy for cancer tests on mice and humans. Pharmacol Biochem Behav 1984;21:1-5.

13 Sartori HE: Cesium therapy in cancer patients. Pharmacol Biochem Behav 1984;21:11-13.

14 Young F, Bolt J: Torsades de pointes - a report of a case induced by caesium taken as a complementary medicine, and the literature review. J Clin Pharm Ther 2013;38:254-257.

15 ICRP: Age-dependent doses to members of the public from intake of radionuclides. Ann ICRP 1989;20:5358.

16 Rundo J, Newton D: Some recent measurement of caesium-137 and zirconium-95 in human beings. Nature 1962;195:851-854.

17 Rundo J, Mason JI, Nweton D, Taylor BT: Biological half-life of caesium in man in acute and chronic exposure. Nature 1963;200:188-189.

18 Mathew W, Wendy G, Daisy B, Mattman A, Mock T, Brown R: Cesium chloride-induced torsades de pointes. Can J Cardiol 2009;25:e329-e331.

19 U.S. Food and Drug Administration [Internet]: FDA alerts health care professionals of significant safety risks associated with cesium chloride [cited 2018 Jul 23]. URL: https://www.fda.gov/Drugs/ GuidanceComplianceRegulatoryInformation/PharmacyCompounding/ucm614211.htm

20 Aschenbrenner DS: Cesium chloride, used as alternative cancer therapy, poses risk. Am J Nurs 2018;118:20.

21 Middleton RJ: Hexokinases and glucokinases. Biochem Soc Trans 1990;18:180-183.

22 Wilson JE: Hexokinase. Rev Physiol Biochem Pharmacol 1995;126:65-198.

23 Pedersen PL, Mathupala S, Rempel A, Geschwind JF, Ko YH: Mitochondrial bound type II hexokinase: a key player in the growth and survival of many cancers and an ideal prospect for therapeutic intervention. Biochem Biophys Acta 2002;1555:14-20.

24 Pastrino JG, Hoek JB: Hexokinase II: The integration of energy metabolism and control of apoptosis. Curr Med Chem 2003;10:1535-1551.

25 Christofk HR, Vander Heiden MG, Harris MH, Ramanathan A, Gerszten RE, Wei R, Fleming MD, Schreiber SL, Cantley LC: The M2 splice isoform of pyruvate kinase is important for cancer metabolism and tumor growth. Nature 2008;452:230-233.

26 Christofk HR, Vander Heiden MG, Wu N, Asara JM, Cantley LC: Pyruvate kinase M2 is a phosphotyrosinebinding protein. Nature 2008;452:181-186.

27 Cribbs RM, Kline ES: The effect of environment on lactate dehydrogenase isozymes of cultured somatic cells. J Cell Physiol 1971;78:59-64.

28 Kobayashi D, Kakinouchi K, Nagae T, Nagai T, Shimura K, Hazama A: Cesium reversibly suppressed HeLa cell proliferation by inhibiting cellular metabolism. FEBS Lett 2017;591:718-727.

29 Ziasmin K, Nishimura N, Kobayashi D, Hazama A: Cesium suppresses fibroblast proliferation and migration. Fukushima J Med Sci 2020;66:97-102.

30 Gilles C, Polette M, Coraux C, Tournier JM, Meneguzzi G, Munaut C, Volders L, Rousselle P, Birembaut P, Foidart JM: Contribution of MT1-MMP and of human laminin-5 $\gamma 2$ chain degradation to mammary epithelial cell migration. J Cell Sci 2001;114:2967-2976. 


\section{Cellular Physiology Cell Physiol Biochem 2021;55:477-488 \begin{tabular}{ll|l|l|l}
\hline DOI: 10.33594/000000399 & ( 2021 The Author(s). Published by \\
\hline
\end{tabular} \begin{tabular}{ll} 
Published online: 11 August 2021 & Cell Physiol Biochem Press GmbH\&Co. KG \\
\hline
\end{tabular} \\ Kobayashi et al.: Cesium Depresses Glycolysis Pathway}

31 Piette C, Deprez M, Roger T, Noël A, Foidart JM, Munaut C: The dexamethasone-induced inhibition of proliferation, migration, and invasion in glioma cell lines is antagonized by macrophage migration inhibitory factor (MIF) and can be enhanced by specific MIF inhibitors. J Biol Chem 2009;284:3248332492.

32 Espada-Murao LA, Morita K: Delayed cytosolic exposure of Japanese encephalitis virus double-stranded RNA impedes interferon activation and enhances viral dissemination in porcine cells. J Virol 2011;85:67366749.

33 Duan YL, Ye HQ, Zavala AG, Yang CQ, Miao LF, Fu BS, Seo KS, Davrinche C, Luo MH, Fortunato EA: Maintenance of Large Numbers of Virus Genomes in Human Cytomegalovirus-Infected T98G Glioblastoma Cells. J Virol 2014;88:3861-3873.

34 Shiratori R, Furuichi K, Yamaguchi M, Miyazaki N, Aoki H, Chibana H, Ito K, Aoki S: Glycolytic suppression dramatically changes the intracellular metabolic profile of multiple cancer cell lines in a mitochondrial metabolism-dependent manner. Sci Rep 2019;9:18699.

35 Pajak B, Siwiak E, Soltyka M, Priebe A, Zielinsk R, Fokt I, Ziemniak M, Jaśkiewicz A, Borowski R, Domoradzki T, Priebe W: 2-Deoxy-D-glucose and its analogs: From diagnostic to therapeutic agents. Int J Mol Sci 2019;21:234.

36 Christensen CE, Karlsson M, Winther JR, Jensen PR, Lerche MH: Non-invasive in-cell determination of free cytosolic $[\mathrm{NAD}+] /[\mathrm{NADH}]$ ratios using hyperpolarized glucose show large variations in metabolic phenotypes. J Biol Chem 2014;289:2344-2352.

37 Fantin CR, St-Pierre J, Leder P: Attenuation of LDH-A expression uncovers a link between glycolysis, mitochondrial physiology, and tumor maintenance. Cancer Cell 2006;9:425-434.

38 Le A, Cooper CR, Gouw M, Dinavahi R Maitra A, Deck LM: Inhibition of lactate dehydrogenase A induces oxidative stress and inhibits tumor progression. Pro Natl Sci Acad USA 2010;107:2037-2042. 